\title{
Role of ER $\beta$ palmitoylation in the inhibition of human colon cancer cell proliferation
}

\author{
Paola Galluzzo, Francesco Caiazza, Sandra Moreno and Maria Marino \\ Department of Biology, University 'Roma Tre', Viale G Marconi, 446,I-00146 Roma, Italy \\ (Requests for offprints should be addressed to M Marino; Email: m.marino@uniroma3.it)
}

\begin{abstract}
The cellular functions regulated by $17 \beta$-estradiol (E2) start after the hormone binds to its receptors (i.e., ER $\alpha$ and $E R \beta$ ). These act as ligand-dependent transcription factor transactivating target genes. In addition, E2 induces non-genomic actions, whose activation is triggered by a fraction of the ERs localized at the plasma membrane. Palmitoylation allows ER $\alpha$ to localize at the plasma membrane, to associate with caveolin-1, and, upon E2 stimulation, to activate rapid signals relevant for cell proliferation. The existence of a mechanism, which allows ER $\beta$ localization at the plasma membrane and its putative role in anti-proliferative E2 effects is completely unknown. Here, the susceptibility of ER $\beta$ to undergo palmitoylation and the role played by this process has been analyzed in DLD-1 containing endogenous ER $\beta$ or in HeLa cells transiently transfected with $\mathrm{ER} \beta$ or $\mathrm{ER} \alpha$ expression vectors. As for $\mathrm{ER} \alpha$, palmitoylation is necessary for $\mathrm{ER} \beta$ localization at the plasma membrane and its association with caveolin-1 but, in contrast to $E R \alpha$, the E2 binding increases ER $\beta$ association with caveolin-1 and the p38 member of MAPK family. Moreover, the palmitoyl acyl transferase (PAT) inhibitor blocks the ability of ER $\beta-E 2$ complex to activate p38 impairing the receptor-dependent activation of downstream pro-apoptotic cascade (i.e., caspase3 activation and poly(ADP-ribose)polymerase (PARP) cleavage). Consequently, palmitoylation must be considered to be a molecular device for $E R \beta$, which allows these receptors to interact with the plasma membrane and to regulate E2-induced non-genomic functions relevant to the antiproliferative effect of this hormone.
\end{abstract}

Endocrine-Related Cancer (2007) 14 153-167

\section{Introduction}

Knowledge of the pleiotropic functions regulated by $17 \beta$-estradiol (E2) in different tissues and organs has evolved rapidly during the past decade. It is now well established that the E2 effects in living cells are mediated by a complex signaling network rather than a single uniform mechanism. In fact, in addition to its role as gene transcription regulator (Acevedo \& Kraus 2004), sustained by the two estrogen receptors (ER $\alpha$ and ER $\beta$ ), E2 induces rapid, membrane starting, nongenomic actions (Levin 2005, Marino et al. 2005, Song et al. 2005, Leclercq et al. 2006).

Among other physiological roles, there is growing evidence that the rapid actions activated when E2 binds to the $\alpha$ isoform of ER are important for cell proliferation. The E2 treatment of mammary-derived MCF-7 cells triggers ER $\alpha$ association with Src, and the regulatory subunit of phosphatidyl inositol 3-kinase, (PI3K) leading to DNA synthesis (Castoria et al. 2001).
Moreover, in HepG2 cells, multiple and parallel membrane starting pathways are rapidly activated by the ER $\alpha-E 2$ complex (Marino et al. 1998, 2002, 2003). The blocking of phospholipase C/protein kinase C, mitogen-activated protein kinase (MAPK)/extracellular regulated kinase (ERK), and PI3K/AKT pathways completely prevents the E2-induced DNA synthesis (Marino et al. 2002, 2003). All these results point to the belief that membrane localized ER $\alpha$ is the primary endogenous mediator of rapid E2 actions important for cell proliferation and survival.

However, recent reports have demonstrated that E2 could even decrease cell growth by significantly increasing apoptosis in several cell types (see Song \& Santen 2003 for review). In particular, epidemiologic, clinical, and experimental evidence show that E2 confers protection against prostate and colon cell proliferation (Horvath et al. 2001, Konstantinopoulos et al. 2003, Bardin et al. 2004, Koehler et al. 2005). 
ER $\beta$ seems to participate in these E2-induced blockages of cell proliferation. A progressive decline of ER $\beta$ expression has been reported in multistage mammary carcinogenesis (Roger et al. 2001) and prostate cancer (Horvath et al. 2001); moreover, ER $\beta$ is the predominant ER expressed in colonic tissues and its expression is selectively lost in human malignant colon tissue (Konstantinopoulos et al. 2003, WadaHiraike et al. 2006). It has been proposed that ER $\beta$ could act as a dominant regulator of E2 signaling (Koehler $e t$ al. 2005), and when co-expressed with ER $\alpha$, it would cause a concentration-dependent reduction in ER $\alpha$ mediated transcriptional activation (Pettersson et al. 1997). The ER $\beta$-directed repression of ER $\alpha$-mediated effects includes cell proliferation (Imamov et al. 2005, Koehler et al. 2005). Data from gene expression in cell cultures and knockout mice, clearly indicate that E2activated ER $\beta$ must have some function as a tumor suppressor by modulating the proliferative effects of $\mathrm{ER} \propto$ (Couse \& Korach 1999, Cheng et al. 2004, Paruthiyil et al. 2004, Strom et al. 2004).

These studies support a functional antagonism between $E R \alpha$ and $E R \beta$ with respect to the E2-induced cell proliferation, but failed either to ascertain the putative role of ER $\beta$ in E2-induced apoptosis or to identify the signal transduction pathways involved. However, the ability of the ER $\beta-E 2$ complex to activate rapid non-genomic mechanisms has been reported (Castoria et al. 2001, Kousteni et al. 2001, Geraldes et al. 2003, Mori-Abe et al. 2003). We recently demonstrated that E2-induced rapid signal transduction pathways in ER $\beta$-transfected HeLa cells appear to play a major role in mediating antiproliferative properties of this steroid hormone. The action of E2 in these cells results from binding to ER $\beta$ which, in turn, acutely promotes the rapid and persistent phosphorylation of the p38 member of MAPK family, thus triggering downstream activation of a pro-apoptotic cascade (Acconcia et al. 2005a). The rapidity by which these cellular cascades are activated raises the need for a receptor localized at the plasma membrane. Although a subpopulation of ER $\beta$ localized within caveolar rafts, responsible for rapid endothelial nitric oxide synthase stimulation by E2 has been reported in the plasma membrane of endothelial cells (Chambliss et al. 2002), the mechanism allowing ER $\beta$ localization at the plasma membrane and its putative involvement in the anti-proliferative effect mediated by ER $\beta-E 2$ complex is completely unknown. We previously demonstrated that the Cys447 residue present in the ER $\alpha$ ligand binding domain (LBD) is palmitoylable and this lipid modification is necessary for the induction of the non-genomic ERK/MAPK signal transduction pathway, which is relevant to E2induced cell proliferation (Acconcia et al. 2005b). Although, the homology between ER $\alpha$ and ER $\beta$ LBDs is only 59\% (Ascenzi et al. 2006), the amino acid sequence encompassing the palmitoylated Cys447 and Cys132 residues of ER $\alpha$ and caveolin-1, respectively, is highly homologous to that surrounding the Cys399 residue of $\operatorname{ER} \beta$ (Acconcia et al. 2003). Based on these findings, we postulated that ER $\beta$ serves as a palmitoyl acyl transferase (PAT) substrate and that the receptor palmitoylation is important for the localization at the membrane and for the activation of the E2-dependent pro-apoptotic cascade in colon cancer cells. Our results indicate that ER $\beta$ palmitoylation is a major determinant for ER $\beta$-membrane and ER $\beta$-protein interaction (i.e., caveolin-1 and p38/MAPK) important for the E2induced protective effect against colon cancer.

\section{Materials and methods}

\section{Reagents}

E2, gentamicin, penicillin, GenElute plasmid maxiprep kit, Dulbecco Modified Eagle Medium (DMEM), RPMI-1640 medium (without phenol red), charcoalstripped fetal calf serum, and the PAT inhibitor 2-bromohexadecanoic acid (2-bromo-palmitate; 2-Br) $\left(\mathrm{IC}_{50} \simeq 4.0 \mu \mathrm{M}\right.$; Varner et al. 2003), were purchased from Sigma-Aldrich (St Louis, MO, USA). The p38/ MAPK inhibitor, SB 203580 (SB), was obtained from Calbiochem (San Diego, CA, USA). The ER inhibitor ICI 182780 (ICI) was obtained from Tocris (Ballwin, MO, USA). 9,10- $\left[{ }^{3} \mathrm{H}\right]$-palmitic acid (specific activity $57.00 \mathrm{Ci} / \mathrm{mmol}$ ) was purchased from Dupont-NEN (Boston, MA, USA). Lipofectamine reagent was obtained from Gibco-BRL Life-technology. The luciferase kit was obtained from Promega. Bradford Protein Assay was obtained from Bio-Rad Laboratories. The monoclonal anti-phospho-ERK, anti-AKT, anti-Src, anti-caspase-3, anti-poly(ADP-ribose)polymerase (PARP), and anti- $\beta$-actin as well as the polyclonal anti-ERK, anti-caveolin-1, anti-ER $\alpha$ MC20 (C-terminus), and anti-ER $\beta$ L20 (C-terminus) antibodies were obtained from Santa Cruz Biotechnology (Santa Cruz, CA, USA). The monoclonal anti-ER $\beta$ 14C8 (N-terminus) antibody was purchased from Genetex (San Antonio, TX, USA). The policlonal anti-phospho-AKT, anti-phospho-p38, and anti-p38 antibodies were obtained by New England Biolabs (Beverly, MA, USA). The modulator of non-genomic activity of estrogen receptor (MNAR, also named Pro-, Glu-, and Leu-rich protein-1; PELP1) polyclonal antibody was purchased from Benthyl Laboratories 
(Montgomery, TX, USA). CDP-Star, chemiluminescence reagent for Western blot was obtained from NEN. All the other products were from SigmaAldrich. Analytical or reagent grade products, without further purification, were used.

\section{Cell culture and count}

The ERs-devoid human cervix epithelioid carcinoma cell line (HeLa; Marino et al. 2002) and the ER $\beta$ containing human colon adenocarcinoma cells (DLD1; Marino et al. 2006) were used as experimental models. Cells were routinely grown in air containing $5 \% \mathrm{CO}_{2}$ in modified, phenol red-free, DMEM (HeLa cells) or RPMI-1640 (DLD-1 cells) media, containing $10 \%(\mathrm{v} / \mathrm{v})$ charcoal-stripped fetal calf serum, Lglutamine $(2 \mathrm{mM})$, gentamicin $(0.1 \mathrm{mg} / \mathrm{ml})$, and penicillin $(100 \mathrm{U} / \mathrm{ml})$. Cells were passaged every 2 days and media changed every 2 days.

DLD-1 cells were grown to approximate $70 \%$ confluence in six-wells plates then stimulated. Thirty hours after treatment $(10 \mathrm{nM} \mathrm{E} 2,1 \mu \mathrm{M}$ ICI 182780 , $10 \mathrm{nM}$ E2-BSA), cells were harvested with trypsin and centrifuged. Cells were stained with the Trypan blue solution and counted in a hemocytometer (improved Neubauer chamber) in quadruplicate.

\section{Plasmids}

The reporter plasmid containing the promoter of complement component 3 gene, retaining a natural estrogen responsive element (ERE), linked to the gene of luciferase ( $\mathrm{pC} 3$ ), the reporter plasmid containing the promoter of cyclin D1 pXP2- $D_{1}-2966$-luciferase (pD1), the expression vector $\mathrm{pCR} 3.1-\beta$-galactosidase, wild type human ER $\alpha$ pSG5-HE0, human ER $\beta$ (pCNX2-ER $\beta$ ) have been described elsewhere (Herbert et al. 1994, Marino et al. 2002, Acconcia et al. 2004, 2005a). A luciferase dose-response curve showed that the maximum effect was obtained when $1.0 \mu \mathrm{g}$ of plasmids was transfected together with $1.0 \mu \mathrm{g}$ of pCR3.1- $\beta$-galactosidase to normalize for transfection efficiency (approximate 55-65\%). Plasmids were purified for transfection using the GenElute plasmid maxiprep kit according to the manufacturer's instructions.

\section{Transfection and luciferase assay}

HeLa and DLD-1 cells were grown to $\sim 70 \%$ confluence and then transfected using lipofectamine reagent according to the manufacturer's instructions. Six hours after transfection, the medium was changed and $24 \mathrm{~h}$ after the cells were stimulated with $10.0 \mathrm{nM}$
E2 for $6 \mathrm{~h}$. The cell lysis procedure as well as the subsequent measurement of luciferase gene expression was performed using the luciferase kit according to the manufacturer's instructions with an EC \& G Berthold luminometer (Bad Wildbad, Germany). When indicated, the PAT inhibitor 2-Br (final concentration $10.0 \mu \mathrm{M}$ ) was added 15 min before E2 administration.

\section{Cell labelling with $\left[{ }^{3} \mathrm{H}\right]$-palmitate and immunoprecipitation}

Twenty-four hours after transfection with either plasmid containing ER $\alpha$ or ER $\beta$, HeLa cells and untransfected DLD-1 cells were incubated with $0.5 \mathrm{mCi} / \mathrm{ml}\left[{ }^{3} \mathrm{H}\right]$-palmitate at $37{ }^{\circ} \mathrm{C}$ for different times ranging between 0 and 240 min. DLD- 1 and HeLa cells were stimulated with different concentrations of E2 $(0.1,1.0,10.0$, and $100.0 \mathrm{nM})$ for different times $(10$, 60 , and $240 \mathrm{~min}$ ) in the presence of $\left[{ }^{3} \mathrm{H}\right]$-palmitate. Cells were then washed in ice-cold PBS, harvested with trypsin $(1 \%, \mathrm{v} / \mathrm{v})$, and lysed in $50 \mu \mathrm{l}$ lysis buffer (10.0 mM Tris, pH 7.5, $1.0 \mathrm{mM}$ EDTA, $0.5 \mathrm{mM}$ EGTA, $10.0 \mathrm{mM} \mathrm{NaCl}, 1 \%(\mathrm{v} / \mathrm{v})$ Triton X-100, and $1 \%(\mathrm{w} / \mathrm{v})$ sodium cholate) containing protease inhibitors $(0.5 \mathrm{mM}$ phenylmethylsulfonyl fluoride, $1.0 \mu \mathrm{g} / \mathrm{ml} \mathrm{leupeptin,} \mathrm{and} 5.0 \mu \mathrm{g} / \mathrm{ml}$ aprotinin). The cell lysates were then clarified by centrifugation and immunoprecipitated as described previously (Acconcia et al. 2005b). Briefly, equal amounts of soluble cell extracts were incubated with different anti-ER $\beta$ antibodies. The optimal signal was obtained using $1.0 \mu \mathrm{g}$ anti-ER $\beta$ L10 (C-terminus) together with $1.0 \mu \mathrm{g}$ of anti-ER $\beta$ 14C8 ( $\mathrm{N}$-terminus). The lysates and antibodies were incubated for $90 \mathrm{~min}$ at $4{ }^{\circ} \mathrm{C}$, and then $20 \mu \mathrm{l}$ of protein-A agarose were added for $30 \mathrm{~min}$ at $4{ }^{\circ} \mathrm{C}$. After centrifugation $(50000 \mathrm{~g}$ for $15 \mathrm{~min})$, the supernatant and the immunoprecipitated proteins were separated in 7-10\% SDS-PAGE. In some experiments, the radioactivity present in immunoprecipitated proteins and in the supernatant was monitored by counting with a Camberra Packard Liquid $\beta$-counter (Milan, Italy).

\section{True-blot immunoprecipitation}

The cell lysates, prepared as described above, were clarified by centrifugation and immunoprecipitated with TrueBlot (eBioscience, San Diego, CA, USA), which preferentially detects the native disulfide form of mouse $\mathrm{IgG}$ or rabbit $\mathrm{IgG}$ reducing interference by approximate $55 \mathrm{kDa}$ heavy and approximate $23 \mathrm{kDa}$ light chains of the immunoprecipitating antibody. Briefly, after stimulation, equal amounts of soluble cell extracts were incubated with either $2.0 \mu \mathrm{g}$ of 
anti-caveolin-1 or anti-p38 or anti-Src or anti-MNAR or anti-14C8 ER $\beta$ antibody. The lysates and antibodies were incubated at $4{ }^{\circ} \mathrm{C}$ for $1 \mathrm{~h}$, then $20 \mu \mathrm{l}$ of Anti Mouse IgG Beads (eBioscience) were added and samples incubated for $1 \mathrm{~h}$ on a rocking platform at $4{ }^{\circ} \mathrm{C}$. Samples were centrifuged at $50000 \mathrm{~g}$ for $10 \mathrm{~min}$, the supernatant was removed completely and beads (pelleted) were washed three times with $100 \mu$ of lysis buffer. SDS-reducing sample buffer $(20 \mu 1$, containing $50 \mathrm{mM}$ DTT) was added and samples were boiled at $100{ }^{\circ} \mathrm{C}$ for $5 \mathrm{~min}$. Proteins were resolved using $10 \%$ SDS-PAGE at $100 \mathrm{~V}$ for $1 \mathrm{~h}$ and then electrophoretically transferred to nitrocellulose for $45 \mathrm{~min}$ at $100 \mathrm{~V}$ at $4{ }^{\circ} \mathrm{C}$. The nitrocellulose was treated with $5 \%(\mathrm{w} / \mathrm{v})$ non-fat dry milk (Bio-Rad Laboratories) in $150 \mathrm{mM}$ $\mathrm{NaCl}, 50.0 \mathrm{mM}$ Tris $\mathrm{HCl}$ (pH 8.0), 0.1\% (w/v) Tween20 , and then probed at $4{ }^{\circ} \mathrm{C}$ overnight with anti-ER $\beta$ antibody. The antibody reaction was visualized with the chemiluminescence reagent for Western blot.

\section{Immuno-fluorescence studies}

DLD- 1 cells were grown on coverslips, treated as above specified, and fixed in $2 \%(\mathrm{w} / \mathrm{v})$ freshly de-polymerized $p$-formaldehyde (Sigma-Aldrich) and $0.2 \%$ (v/v) glutaraldehyde (Agar Scientific Ltd, Stanstead, UK) in PBS. Cells were then incubated with $14 \mathrm{C} 8$ anti-ER $\beta$ mouse monoclonal antibody diluted 1:100 in PBS containing $1 \%(\mathrm{w} / \mathrm{v}) \mathrm{BSA}$ and $0.1 \%(\mathrm{v} / \mathrm{v})$ Triton X-100. After washing, cells were incubated with goat antimouse fluorescein isothiocynate (FITC)-conjugated antibody (Vector Laboratories, Burlingame, CA, USA; diluted 1:200 in PBS containing 1\% (w/v) BSA and $0.1 \%(\mathrm{v} / \mathrm{v})$ Triton $\mathrm{X}-100)$. Finally, slides were mounted with Vectashield (Vector Laboratories) and localization of the receptor was examined with a Zeiss LSM510 confocal microscope. Pictures were electrically captured and composed by Photoshop 7.0 software.

\section{RNA isolation and quantitative RT-PCR analysis (qRT-PCR)}

The sequences for gene-specific forward and reverse primers were designed using the OligoPerfect Designer software program (Invitrogen). The following primers were used: for human $\mathrm{ER} \alpha$ (ESR1/NR3A1, GeneBank Accession No. AY425004), 5'-TCCTAGCAGGGAGATGAGGA-3' (forward) and 5'-CCTTTATGGCCAGCAATCAT- $3^{\prime}$ (reverse), for human ER $\beta$ (ESR2/NR3A2, GeneBank Accession No. AY785359), 5'-GGCGCGATCTTGGCTCAC-3' (forward) and 5'-TGGCTGGACGTGGTGGCA- $3^{\prime}$ (reverse), and for $\beta$-actin (GeneBank
Accession No. X00351), 5'-AGAAGGATTCCTATGTGGGCG-3' (forward) and $5^{\prime}$-CATGTCGTCCCAGTTGGTGAC- $3^{\prime}$ (reverse).

Total RNA was extracted from DLD-1 cells using TRIzol Reagent (Invitrogen) according to the manufacturer's instructions. To determine hER- $\beta$ gene expression levels (as well to confirm the absence of hER- $\alpha$ ), cDNA synthesis and qPCR were performed using a one-step qRT-PCR kit ('SuperScript III Platinum - SYBR Green One-Step' kit; Invitrogen) according to the manufacturer's instructions. cDNA synthesis and qPCR was carried out in a ABI Prism 7900HT Sequence Detection System (Applied Biosystems, Foster City, CA, USA) as follows: first strand cDNA synthesis was performed at $50{ }^{\circ} \mathrm{C}$ for $5 \mathrm{~min}$, followed by an automatic hot-start Taq DNA Polimerase activation step at $95^{\circ} \mathrm{C}$ for $5 \mathrm{~min}$, and then by 25 cycles of denaturation at $95{ }^{\circ} \mathrm{C}$ for $15 \mathrm{~s}$, annealing at $60{ }^{\circ} \mathrm{C}$ for $30 \mathrm{~s}$, and elongation at $40{ }^{\circ} \mathrm{C}$ for $1 \mathrm{~min}$. Gene expression was verified by electrophoresis on $2 \%$ agarose gel. Each sample was tested in duplicate and the experiment repeated four times.

\section{Electrophoresis and immunoblotting}

After treatment, cells were lysed and solubilized in $0.125 \mathrm{M}$ Tris, $\mathrm{pH}$ 6.8, containing 10\% (w/v) SDS, $1.0 \mathrm{mM}$ phenylmethylsulfonyl fluoride, and $5.0 \mu \mathrm{g} / \mathrm{ml}$ leupeptin; then the cell lysates were boiled for $2 \mathrm{~min}$. In some experiments cells were homogenized using ten strokes of the pestle of Potter homogenizer until about $90 \%$ of the cells were broken. Homogenates were centrifuged at $1000 \mathrm{~g}$ for $10 \mathrm{~min}$ to pellet the nuclear fraction. Soluble and particulate fractions were obtained by centrifuging the supernatants at $100000 \mathrm{~g}$ for $30 \mathrm{~min}$. Proteins were solubilized as above described. Total proteins were quantified using the Bradford Protein Assay. Solubilized proteins $(20 \mu \mathrm{g})$ were resolved by $10 \%$ SDS-PAGE at $100 \mathrm{~V}$ for $1 \mathrm{~h}$ at $24^{\circ} \mathrm{C}$ and then electrophoretically transferred to nitrocellulose for $45 \mathrm{~min}$ at $100 \mathrm{~V}$ and $4{ }^{\circ} \mathrm{C}$. The nitrocellulose was treated with $3 \%(\mathrm{w} / \mathrm{v}) \mathrm{BSA}$ in $138.0 \mathrm{mM} \mathrm{NaCl}, 25.0 \mathrm{mM}$ Tris, $\mathrm{pH} 8.0$, at $24{ }^{\circ} \mathrm{C}$ for $1 \mathrm{~h}$ and then probed overnight at $4{ }^{\circ} \mathrm{C}$ with either antiphospho-ERK or anti-phospho-AKT or anti-phosphop38 or anti-ER $\beta$ antibodies. The nitrocellulose was stripped by Restore Western Blot Stripping Buffer (Pierce Chemical Company, Rockford, IL, USA) for $10 \mathrm{~min}$ at room temperature and then probed with either anti-ERK or anti-AKT or anti-p38 or anticaspase- 3 or anti-PARP and anti- $\beta$-actin antibodies. Antibody reaction was visualized with chemiluminescence Western blotting detection reagent 
(Amersham Biosciences). The PAT inhibitor 2- $\mathrm{Br}$ $(10.0 \mu \mathrm{M})$ or the p38 inhibitor SB $203580(5 \mu \mathrm{M})$ was added $30 \mathrm{~min}$ before $\mathrm{E} 2$ administration.

\section{Statistical analysis}

A statistical analysis was performed by utilising Student's $t$-test with the INSTAT software system for Windows. Some data were analyzed by one-way ANOVA and post hoc Bonferroni's test (INSTAT software system for Windows). In all cases probability $(P)$ values below 0.05 were considered significant.

\section{Results}

\section{E2 reduces DLD-1 cell growth}

The main difficulty in studying ERs action mechanism in cancer cells derives from the expression of a great number of ERs splice variants (Herynk \& Fuqua 2004). To bypass this problem we chose human colon adenocarcinoma (DLD-1) cells as an experimental model, which contain only one ER $\beta$ isoform corresponding to $54 \mathrm{kDa}$ protein (Fig. 1A and B). As already reported (Marino et al. 2006), E2 stimulation decreases DLD-1 cell growth. This effect requires ER $\beta$, since it is completely prevented by ICI 182780 (Fig. 1, panel C). Stimulation of DLD- 1 cells with the E2 cell membrane impermeable E2-BSA, a well-known agent able to discriminate between non-genomic vs genomic effects of ER(s) (Marino et al. 2003), affected DLD-1 cell growth, as did E2 (Fig. 1, panel C). This indicates the pivotal role of plasma membrane-starting signals in E2-induced anti-proliferative effects.

\section{ER $\beta$ is a palmitoylable protein}

We first verified the occurrence of ER $\beta$ palmitoylation in DLD-1 cells. Cells were incubated with $\left[{ }^{3} \mathrm{H}\right]-$ palmitate at $37^{\circ} \mathrm{C}$ for different periods (from 0 to $240 \mathrm{~min}$ ) and the amount of radioactivity in both the immunoprecipitate and the supernatant was determined (Fig. 2A). ER $\beta$ and radioactivity were not detected in the supernatant fractions (Fig. 2A and data not shown). $\left[{ }^{3} \mathrm{H}\right]$-palmitate incorporation in immunoprecipitated ER $\beta$ was complete within $120 \mathrm{~min}$ and remained unchanged over $240 \mathrm{~min}$ (Fig. 2B). As a positive control, the radioactivity present in the palmitoylated caveolin-1 (Resh 1999), immunoprecipitated from DLD-1 cells, was measured (Cav-1) (Fig. 2C). A significant decrease in ER $\beta$ and caveolin1 palmitoylation occurred in DLD-1 cells pre-treated with the PAT inhibitor, 2-bromohexadecanoic acid
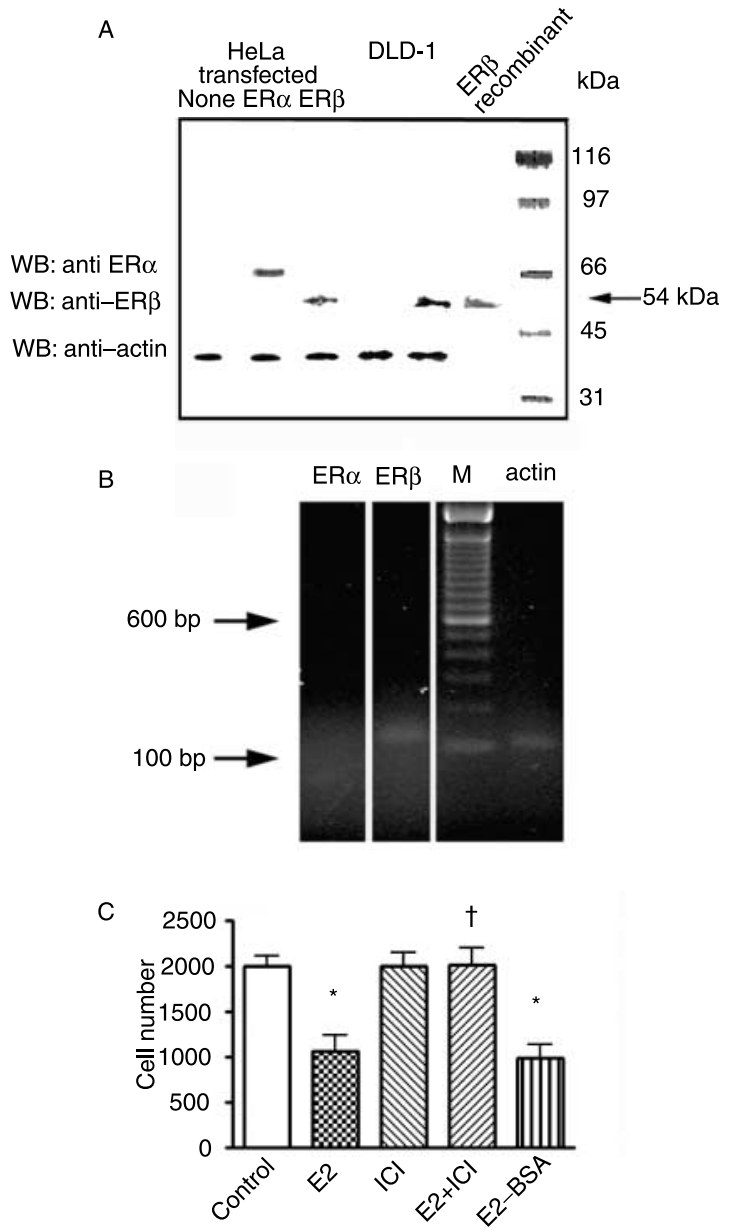

Figure 1 Level of ERs in DLD-1 cells. (A) Western blot analysis of $E R \alpha$ and $E R \beta$ levels were performed in DLD-1 and HeLa cells. HeLa cells were untransfected (none) or transfected with $\mathrm{ER} \alpha$ or $\mathrm{ER} \beta$ expression vectors. Fifty four kilodaltons of human $\mathrm{ER} \beta$ recombinant protein (5 $\mathrm{ng}$, Invitrogen) was used as control. (B) Identification of ER $\beta$ mRNA by RT-PCR using specific sense/antisense primers. Amplification products were separated by electrophoresis on $2 \%$ agarose and identified by ethidium bromide staining. $\mathrm{ER} \beta=108 \mathrm{bp}$; $\mathrm{ER} \alpha=248 \mathrm{bp}$. (C) DLD-1 cells grown for $30 \mathrm{~h}$ in the presence of E2 $(10 \mathrm{nM})$ and/or ICI $182780(\mathrm{ICl}, 1 \mu \mathrm{M})$ or E2-BSA $(10 \mathrm{nM})$ and then counted. The data are the mean values \pm s.D. of five independent experiments carried out in duplicate. $P<0.001$, calculated with Student's $t$-test, compared with respective unstimulated values (control) $\left({ }^{*}\right)$ or with E2-stimulated values $\left({ }^{\dagger}\right)$. For details see text.

(2-Br) (Fig. 2C). These findings indicate that $\mathrm{ER} \beta$, like caveolin-1, undergo PAT-dependent palmitoylation.

The time course for $\left[{ }^{3} \mathrm{H}\right]$-palmitate incorporation in $\mathrm{ER} \beta$ was different to that reported for $\mathrm{ER} \alpha$ (Acconcia et al. 2004). Since, the PATs are a heterogeneous group of enzymes, which differ depending on the cell type (Smotrys \& Linder 2004), we compared the kinetics of $\left[{ }^{3} \mathrm{H}\right]$-palmitate incorporation in the same cell line. The ERs-devoid human cervix epithelioid carcinoma cell 
(HeLa) were transiently transfected with either ER $\alpha$-or ER $\beta$-encoding vectors and then incubated with $\left[{ }^{3} \mathrm{H}\right]$-palmitate for $4 \mathrm{~h}$ at $37^{\circ} \mathrm{C}$. After ER $\alpha$ or ER $\beta$ immunoprecipitation, the radioactivity present in the supernatant was determined. ER $\alpha$ palmitoylation was very rapid being complete within $10 \mathrm{~min}$ and remaining constant over $240 \mathrm{~min}$ (Fig. 2D). Kinetics of $\left[{ }^{3} \mathrm{H}\right]$-palmitate incorporation in ER $\beta$ was slow in both
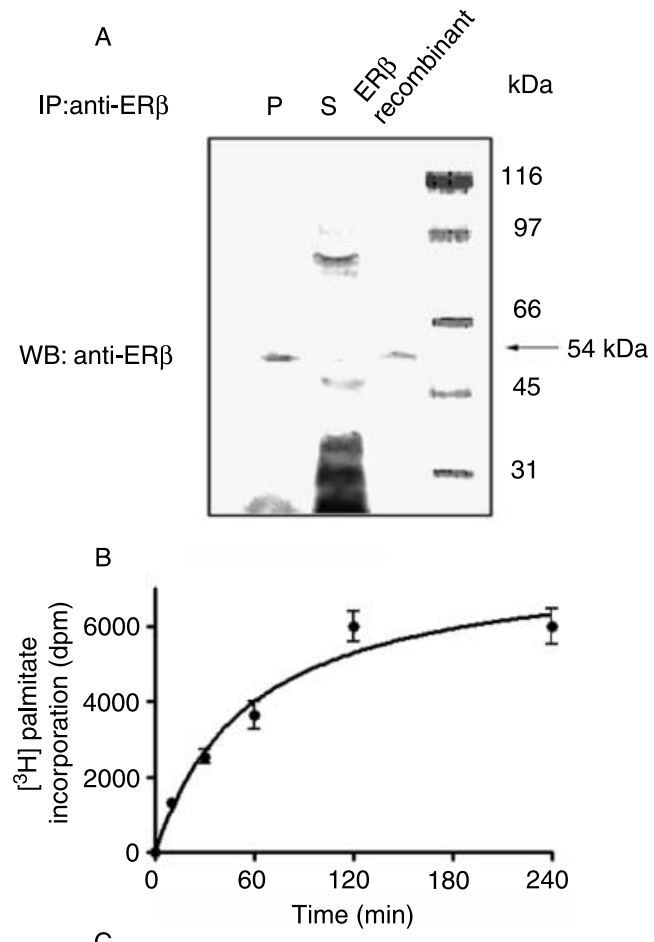

C
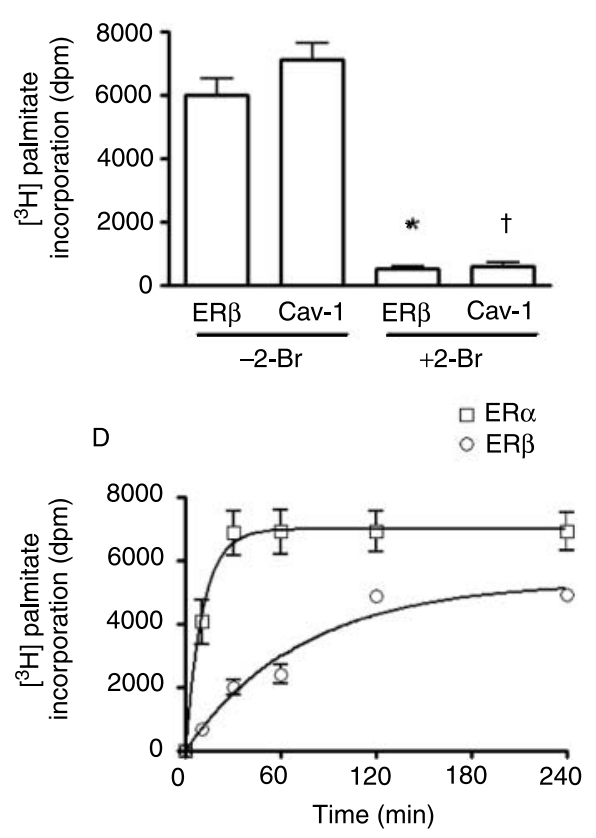

transfected HeLa and DLD-1 cells (Fig. 2, compare panels $B$ and $D$ ). This suggests that ER $\beta$ is a worse substrate than ER $\alpha$ for PAT.

\section{ER $\beta$ palmitoylation is negatively modulated by E2}

To assess the ability of E2 to modulate ER $\beta$ palmitoylation, DLD-1 cells were incubated with $\left[{ }^{3} \mathrm{H}\right]$-palmitate for $4 \mathrm{~h}$ in the presence of different E2 concentrations. Physiological E2 concentration (1-10 nM) decreased the amount of $\left[{ }^{3} \mathrm{H}\right]$-palmitate incorporated in ER $\beta$ by more than half; a higher E2 concentration (i.e., $100 \mathrm{nM}$ ) was more efficient to decrease palmitate incorporation in ER $\beta$, whereas hormone lower concentration was ineffective (i.e., $0.1 \mathrm{nM}$; Fig. 3A). The time course of $10 \mathrm{nM}$ E2 stimulation in DLD-1 cells showed that 60 min of E2 stimulation reduced the $\left[{ }^{3} \mathrm{H}\right]$-palmitate incorporation in ER $\beta$ by $38 \%$ (Fig. 3B) with an increase in the protein level (Fig. 3C). The increase in ER $\beta$ levels were also detected 120 and $240 \mathrm{~min}$ after E2 stimulation (Fig. 3C), which is in good accordance with data reported in the literature (Chiang et al. 2000, Matthews \& Gustafsson 2003 and literature therein). The kinetics of E2-induced de-palmitoylation is very similar for both ERs, as demonstrated in transfected HeLa cells (Fig. 3D).

\section{ER $\beta$ palmitoylation is necessary for receptor- protein association}

Besides, lipid modification, the association with membrane proteins could allow extrinsic proteins to localize at the plasma membrane. After E2 binding, $\mathrm{ER} \alpha$ is able to associate to adaptor and/or signaling proteins, which in turn are responsible for signaling cascade activation important for cell proliferation (Greger et al. 2006). This prompted us to evaluate the ability of ER $\beta$ to interact with some of these signaling proteins, both in the absence and in the presence of $10 \mathrm{nM} \mathrm{E2}$ for $15 \mathrm{~min}$. No association between ER $\beta$ and Src or MNAR was observed before

Figure 2 ER $\beta$ palmitoylation. (A) Western blot analysis of immunoprecipitated $E R \beta$ in the pellet $(P)$ or the supernatant $(S)$. Fifty four kilodaltons of human ER $\beta$ recombinant protein $(5 \mathrm{ng}$, Invitrogen) was used as control. (B) Time course of $\left[{ }^{3} \mathrm{H}\right]$-palmitate incorporation in immunoprecipitated $E R \beta$ in DLD1 cells. Data are the means of six independent experiments \pm S.D. (C) $\left[{ }^{3} \mathrm{H}\right]$-palmitate incorporation (120 min) in immunoprecipitated ER $\beta$ or caveolin-1 (Cav-1) in the presence or absence of PAT inhibitor 2-Bromo-palmitate (2-Br, $10 \mu \mathrm{M})$. (D) Time course of $\left[{ }^{3} \mathrm{H}\right]$-palmitate incorporation in HeLa cells transfected with $\mathrm{ER} \alpha$ or $\mathrm{ER} \beta$ expression vectors. ERs were immunoprecipitated and radioactivity counted. Data are the means of four independent experiments \pm s.D. of duplicate analyses. For details see text. 
A

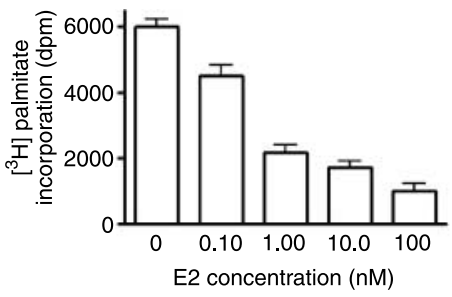

B

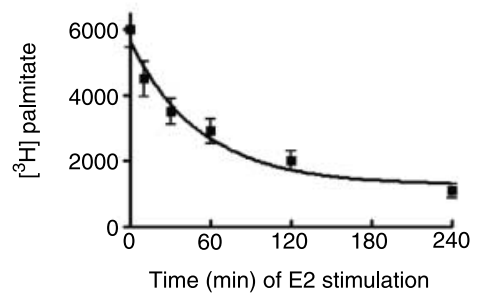

C

Time of E2

Stimulation (min) $\quad 0 \quad 10 \quad 60 \quad 120 \quad 240$

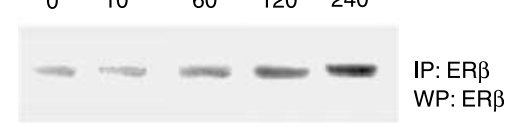

D

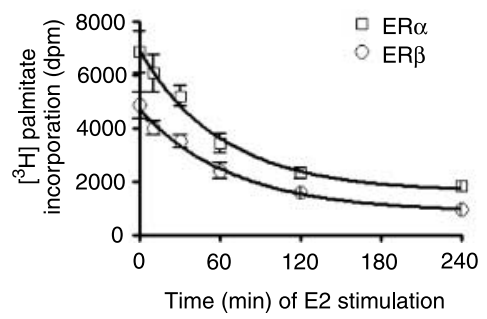

Figure 3 E2 effect on ER $\beta$ palmitoylation. (A) Dose-response curve of E2. $\left[{ }^{3} \mathrm{H}\right]$-palmitate was incorporated in DLD-1 cells for $120 \mathrm{~min}$, then different E2 concentrations were administrated for further 120 min and ER $\beta$ was immunoprecipitated. Data are the means of five independent experiments \pm S.D. (B) Time course of E2 stimulation. $\left[{ }^{3} \mathrm{H}\right]$-palmitate was incorporated in DLD-1 cells for $120 \mathrm{~min}$, then cells were stimulated with $10 \mathrm{nM}$ $\mathrm{E} 2$ at different time and ER $\beta$ was immunoprecipitated. Data are the means of five independent experiments \pm s.D. (C) Typical Western blot of immunoprecipitated ER $\beta$ from DLD-1 cells stimulated with $10 \mathrm{nM}$ E2 at different time. (D) HeLa cells were transfected with human $\mathrm{ER} \alpha$ or human $\mathrm{ER} \beta$ expression vectors. $\left[{ }^{3} \mathrm{H}\right]$-palmitate was incorporated in HeLa cells for 120 min, then cells were stimulated with $10 \mathrm{nM}$ E2 at different time and ER $\beta$ or $\mathrm{ER} \alpha$ were immunoprecipitated. Data are the means of four independent experiments \pm s.D. For details see the text.

or after E2 stimulation of DLD-1 cells (Fig. 4A and B, respectively). This result was followed by the inability of ER $\beta$ to induce ERK or AKT phosphorylation (Fig. $4 \mathrm{C}$ and $\mathrm{D}$, respectively). On the contrary, the association of ER $\beta$ with caveolin-1 is present even in the absence of E2 (Fig. 5A and B). This association increase 60 min after E2 stimulation (Fig. 5A and B). Notably, E2-induced ER $\beta$-caveolin-1 association was completely prevented by pre-treatment with the PAT inhibitor, 2-Br (Fig. 5C). No variation in the level of caveolin-1 was present after E2 stimulation (Fig. 5B).

As a whole, these results suggest that ER $\beta$ palmitoylation is necessary for receptor localization at the plasma membrane. Immunofluorescence and cell fractionation results are consistent with these results (Fig. 6). Under basal conditions, ER $\beta$ is expressed in both membrane and cytoplasm (Fig. 6A, left panel and Fig. 6B), while upon E2 stimulation, the receptor is mainly present at the cell periphery corresponding to the plasma membrane (see the arrows in Fig. 6A, central panel and Fig. 6B). Pre-treatment with the PAT inhibitor abrogates the ability of E2 to re-localizate $\mathrm{ER} \beta$ to the plasma membrane compartment (Fig. 6A, right panel and Fig. 6B).

\section{ERß palmitoylation is necessary for E2-induced pro-apoptotic effects}

In DLD-1 cells, the rapid, persistent E2-induced activation of the p38/MAPK pathway is sufficient and necessary for E2-induced apoptosis (i.e., caspase-3 activation and PARP cleavage; Marino et al. 2006). We next determined whether ER $\beta$ palmitoylation could have an impact on these rapid non-genomic ER $\beta$ activities. E2 induced the rapid and persistent phosphorylation of p38 in DLD-1 cells (Fig. 7A). We investigated whether a physical association existed between $\mathrm{p} 38$ and ER $\beta$ by immunoprecipitation. Under basal conditions a complex formed by the unphosphorylated form of p38 and ER $\beta$ has been detected (Fig. 7B). After 10 min of E2 treatment, ER $\beta-p 38$ association as well as p38 phosphorylation significantly increased (Fig. 7B). However, when the cells were pre-treated with the PAT inhibitor, 2-Br, the E2induced activation of this signaling kinase was completely blocked even though the basal p38 levels were unaffected (Fig. 7C).

We have recently demonstrated that ER-dependent caspase- 3 activation and PARP cleavage are some of the downstream events triggered by E2-induced p38 activation in ERß-transfected HeLa cells (Acconcia et al. 2005a). Accordingly, in DLD-1 cells, E2 induced the cleavage of the caspase-3 proform (32-kDa band), resulting in the production of the active subunit of the protease (17-kDa band; Fig. 8A). To confirm that the appearance of the $17-\mathrm{kDa}$ band was associated with an increase in caspase- 3 activity, we analysed one of the known substrates of caspase-3, namely PARP. This $116-\mathrm{kDa}$, DNA repair enzyme, is cleaved by active caspase- 3 , so produces the inactive $85-\mathrm{kDa}$ fragment. The E2 treatment of DLD-1 cells resulted in the conversion of PARP into the inactive 


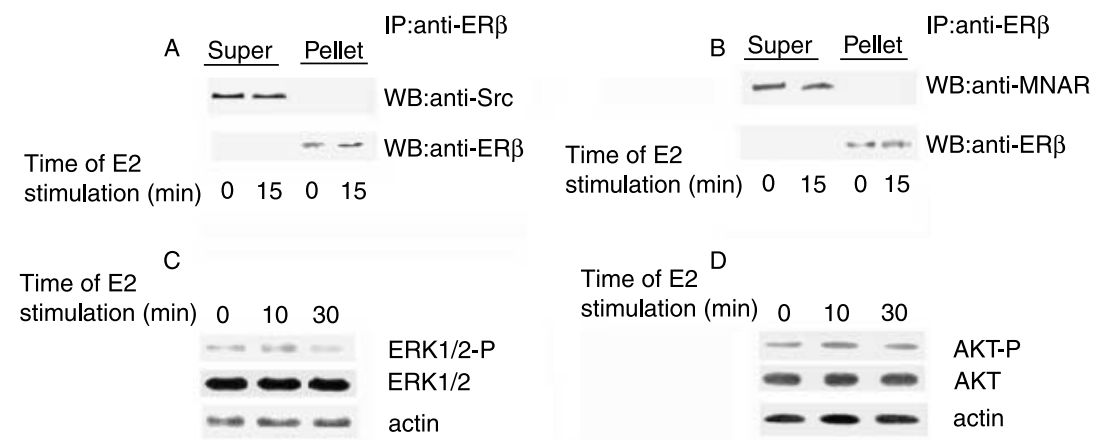

Figure $4 \mathrm{ER} \beta$ association to Src and MNAR and activation of ERK/MAPK and PI3K/AKT pathways in DLD-1 cells. Cells were grown in the absence (0) or stimulated for 15 min with $10 \mathrm{nM}$ E2, ER $\beta$ was immunoprecipitated with anti-ER $\beta$ antibody followed by Western blot with anti-Src (A) or with anti-MNAR (B) and anti-ER $\beta$ antibodies. Western blot analysis of ERK (C) and AKT (D) phosphorylation in DLD-1 cells were performed on unstimulated (0) and stimulated cells for 10-30 min with E2 (10 nM). Data represent a typical Western blot of three different experiments. For details see text.

A

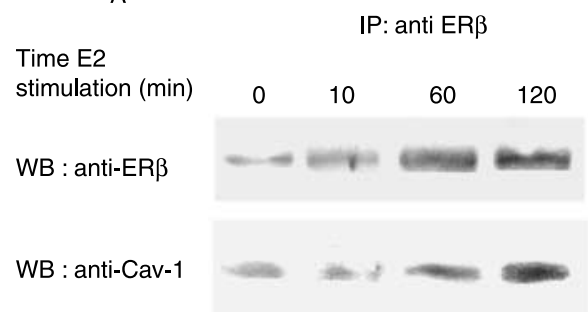

B

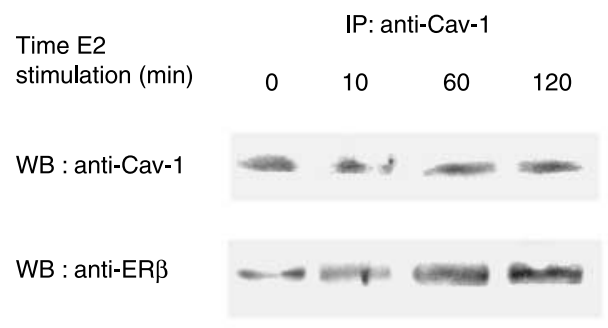

C

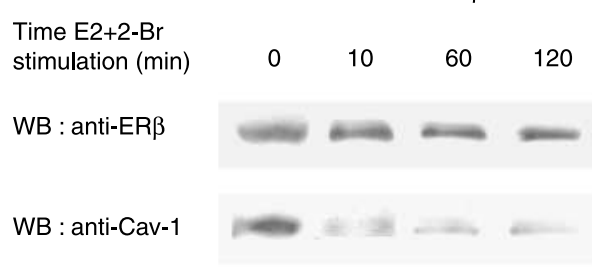

$A^{\prime}$

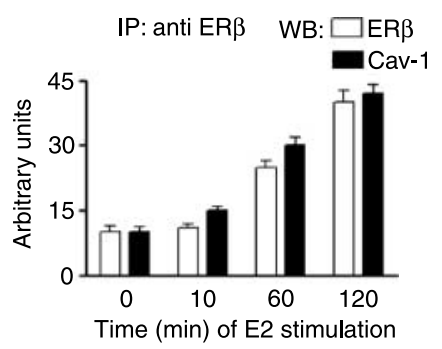

$B^{\prime}$

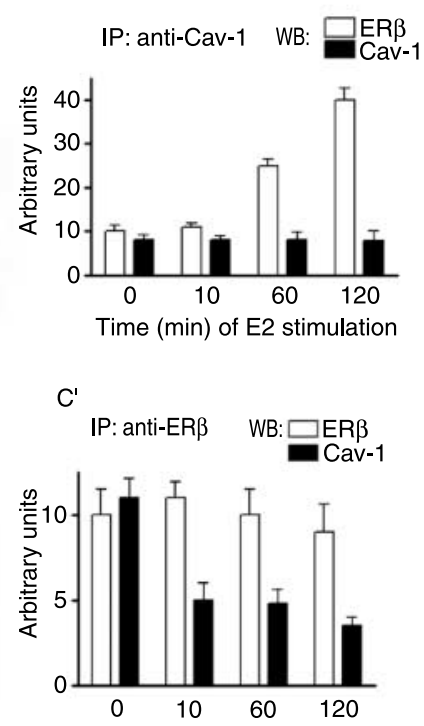

Time ( $\min )$ of E2+2-Br stimulation

Figure 5 Role of ER $\beta$ palmitoylation in ER $\beta$ association to caveolin-1. DLD-1 cells were stimulated with $10 \mathrm{nM}$ E2 for different times then were subjected to $E R \beta$ immunoprecipitation ( $A$ and $A^{\prime}$ ) or caveolin-1 immunoprecipitation (B and $\left.B^{\prime}\right)$ followed by Western blot with anti-caveolin-1 or with anti-ER $\beta$ antibodies. ( $C$ and $C^{\prime}$ ) DLD-1 cells were pre-treated for 30 min with $10 \mu \mathrm{M}$ PAT inhibitor 2-Br then stimulated with $10 \mathrm{nM}$ E2 for different times and subjected to ER $\beta$ immunoprecipitation or caveolin-1 immunoprecipitation followed by Western blot with anti-caveolin-1 or with anti-ER $\beta$ antibodies. (A, B, and C) Typical Western blot; $\left(A^{\prime}, B^{\prime}\right.$, and $\left.C^{\prime}\right)$ densitometric analysis of four different experiments. Data are the mean \pm s.D. For details see text. 
A

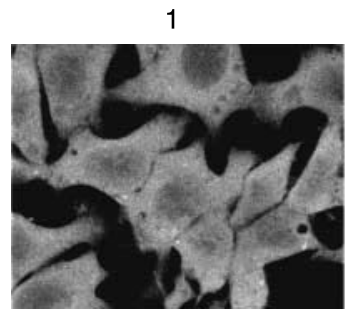

B

WB : anti-ER $\beta$
2

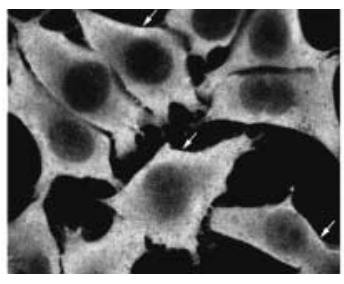

Membrane

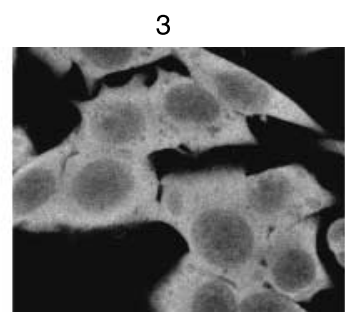

Cytosol

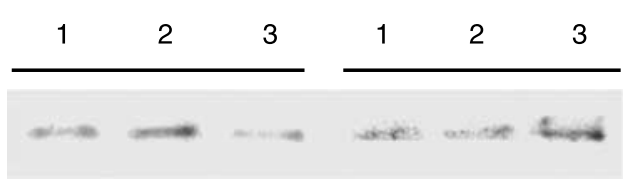

밈m Membrane $\square$ Cytosol

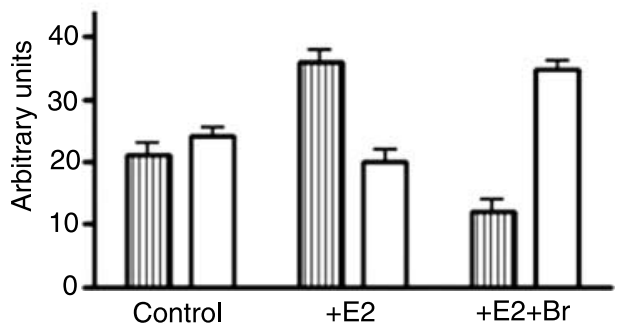

Figure 6 (A) Immuno-fluorescence analysis of unstimulated (left panel), $10 \mathrm{nM}$ E2 stimulated for 120 min (central panel), and pretreated for $30 \mathrm{~min}$ with $10 \mu \mathrm{M}$ PAT inhibitor 2-Br then stimulated with $10 \mathrm{nM}$ E2 for 120 min (right panel) DLD-1 cells. White arrows indicate the membrane localization of ER $\beta$. (B) Cell fractionation assay of unstimulated (1, control), $10 \mathrm{nM}$ E2 stimulated for $120 \mathrm{~min}$ $(2,+E 2)$, and pre-treated for 30 min with $10 \mu \mathrm{M}$ PAT inhibitor 2-Br then stimulated with $10 \mathrm{nM}$ E2 for $120 \mathrm{~min}(3,+\mathrm{E} 2+\mathrm{Br}) \mathrm{DLD}-1$ cells. Typical Western blot (upper panel) and densitometric analysis (bottom panel) of four different experiments. Data are the mean \pm s.D. For details see text.

85-kDa fragment (Fig. 8B). In contrast, neither caspase-3 nor PARP was affected by E2 after the pre-treatment of DLD-1 cells with the PAT inhibitor 2-Br or with the p38 inhibitor SB 203580 (Fig. 8). Notably, no changes in the pro-apoptotic cascade were detected after treatment with both inhibitors, when used alone. Thus, palmitoylated ER $\beta$ must mediate the E2-induced p38 and caspase-3 activation as well as PARP cleavage. These findings demonstrate the critical role played by palmitoylation in ER $\beta$-mediated anti proliferative E2-induced effects.

\section{ER $\beta$ palmitoylation is not necessarily essential for E2-induced transcriptional activity}

We previously demonstrated that ER $\alpha$ palmitoylation is required for E2-induced gene transcription (Acconcia et al. 2005b). Since, we wanted to compare the $E R \alpha$ and $E R \beta$ transcriptional activity in the same cellular context, the ERs devoid HeLa cells were used as experimental model. HeLa cells were co-transfected with the ERE containing $\mathrm{pC} 3$ promoter and $\mathrm{ER} \beta$ or $\mathrm{ER} \alpha$ expression vectors. As expected, in HeLa cells transfected with ER $\alpha$, the E2 treatment induced a three- and a two-fold increase of $\mathrm{pC} 3$ and $\mathrm{pD} 1$ promoter activities, respectively (Fig. 9). On the other hand, in ER $\beta$-transfected HeLa cells E2 induced a twofold increase only on the $\mathrm{pC} 3$ promoter activity (Fig. 9). Notably, the pre-treatment of $\mathrm{ER} \alpha$ or $\mathrm{ER} \beta$ transfected HeLa cells with the PAT inhibitor 2-Br reduced the E2-inducible $\mathrm{pC} 3$ promoter activity by $30 \%$ without affecting the basal $\mathrm{pC} 3$ promoter activity (Fig. 9). As expected, the ER $\alpha$ palmitoylation has a powerful effect on the E2-induced cyclin D1 promoter activity, which is totally impaired by $2-\mathrm{Br}$ treatment, whereas ER $\beta$ was unable to mediate cyclin D1 promoter activity, both in the presence or absence of $2-\mathrm{Br}$. 
A

Time of E2

stimulation (h) $\quad 0 \quad 0.25 \quad 0.5 \quad 24$

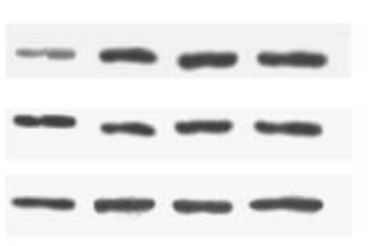

B

Time of E2

stimulation ( $\mathrm{min}$ )

WB: anti-p38-p

WB: anti-p38

WB: anti-ER $\beta$

C

$\mathrm{Tim}$ of $\mathrm{E} 2+2-\mathrm{Br}$

stimulation ( $\mathrm{min})$

$\begin{array}{llll}0 & 10 & 60 & 120\end{array}$

WB: anti-p38-p

WB: anti-p38

WB: anti-ER $\beta$

$$
\text { IP: anti-ER } \beta
$$

$$
\begin{array}{llll}
0 & 10 & 60 & 120
\end{array}
$$

p38-p

p38

actin

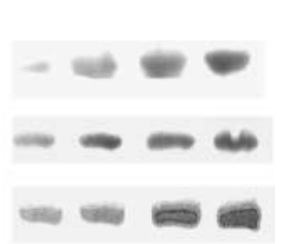

C'

IP: anti ER $\beta$ WB:
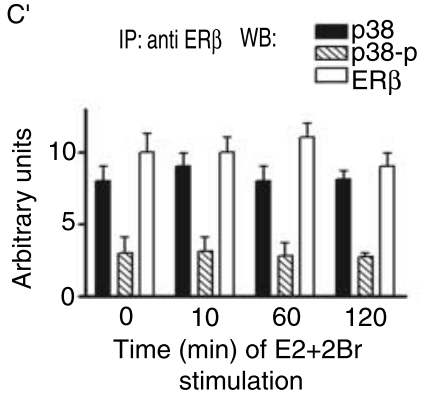

Figure 7 Role of ER $\beta$ palmitoylation on p38/MAPK activation. (A and $A^{\prime}$ ) Time course analysis of p38/MAPK phosphorylation was performed on untreated $(0)$ and E2-treated $(10 \mathrm{nM}) \mathrm{DLD}-1$ cells at the indicated times. The amount of protein levels were normalized by comparison with actin expression. (B and $B^{\prime}$ ) DLD-1 cells were stimulated with $10 \mathrm{nM}$ E2 for different times then were subjected to ER $\beta$ or p38 immunoprecipitation followed by Western blot with anti-p38 or anti-p38 phosphorylated (p38-P) or anti-ER $\beta$ antibodies. (C and $C^{\prime}$ ) DLD-1 cells were pre-treated for 30 min with $10 \mu \mathrm{M}$ PAT inhibitor 2-Br then stimulated with 10 nM E2 for different times and subjected to ER $\beta$ or p38 immunoprecipitation followed by Western blot with anti-p38 or anti-p38 phosphorylated (p38-P) or anti-ER $\beta$ antibodies. (A, B, and C) Typical Western blot; $\left(A^{\prime}, B^{\prime}\right.$, and $\left.C^{\prime}\right)$ densitometric analysis of four different experiments. Data are the mean \pm s.D. For details see text.

\section{Discussion}

Recently, various studies have shown decreased expression of ER $\beta$ mRNA and protein (or an increased $\mathrm{ER} \alpha / \mathrm{ER} \beta$ mRNA ratio) in cancer vs normal tissues in many tumors, including breast, ovary, colon, and prostate (Foley et al. 2000, Campbell-Thompson et al. 2001, Roger et al. 2001, Fixemer et al. 2003, Bardin et al. 2004). Moreover, ER $\beta$ gene is localized on chromosome 14q (see Ascenzi et al. 2006 and references therein), the loss of which has been detected in breast, ovarian, prostate, and colon cancers (Young et al. 1993, Bandera et al. 1997, Loveday et al. 2000, Kasahara et al. 2002). These overall findings suggest a potential tumor-suppressive function for ER $\beta$ (Iwao et al. 2000) that opposes the effects mediated by ER $\alpha-$ E2 complex, which drives cells to proliferation. Thus, the same hormone elicits different effects on cell proliferation by binding to different receptors.

Then, which are the molecular mechanisms underlying the above opposite effects? Like most other members of the nuclear receptor family, ERs have a modular architecture of four interacting domains: the $\mathrm{N}$-terminal A/B domain, the $\mathrm{C}$ or DNA binding domain 
A

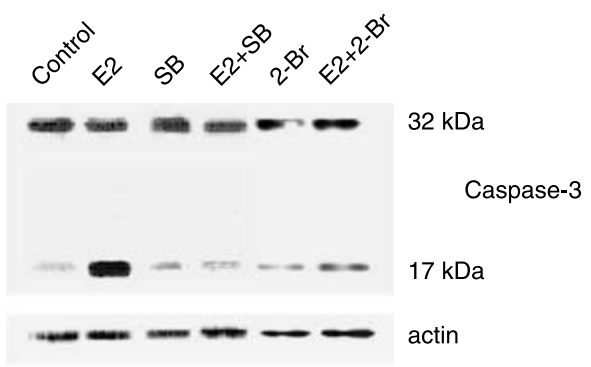

$A^{\prime}$

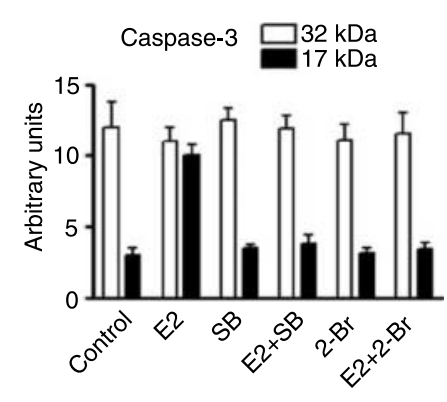

B' PARP $\square 112 \mathrm{kDa}$

B

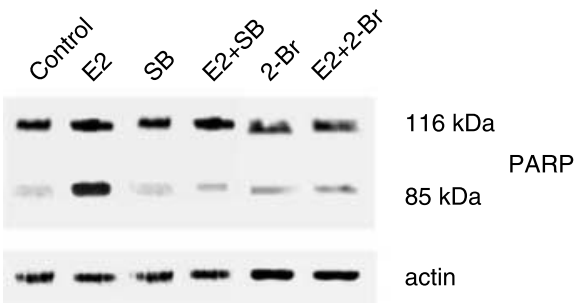

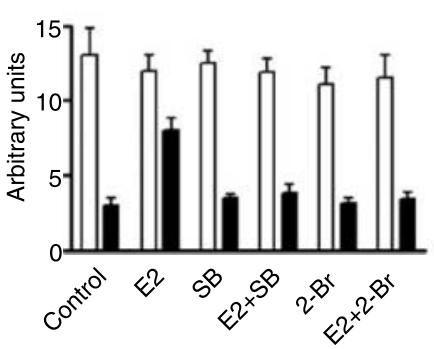

Figure 8 Role of ER $\beta$ palmitoylation on p38-dependent pro-apoptotic cascade activation. (A and $A^{\prime}$ ) Western blot analysis of caspase-3 and PARP (panel b) activation were performed on unstimulated or $24 \mathrm{~h}$ E2-treated (10 nM) DLD1 cells. When indicated $5 \mu \mathrm{M}$ p38/MAPK cascade inhibitor SB 203580 (SB) or $10 \mu \mathrm{M}$ PAT inhibitor 2-Br was added 30 min before E2 administration. The amount of protein levels were normalized by comparison with actin expression. (A and B) Typical Western blot; ( $A^{\prime}$ and $B^{\prime}$ ) densitometric analysis of five different experiments. Data are the mean \pm s.D. For details see text.

(DBD), the $\mathrm{D}$ or hinge domain and the $\mathrm{C}$-terminal $\mathrm{E} / \mathrm{F}$ or LBD (Marino et al. 2005, Ascenzi et al. 2006). The homology in the DBD is 97\% (Ascenzi et al. 2006), which suggests that $E R \alpha$ and $E R \beta$ are capable of regulating gene transcription through a classical mechanism involving the consensus ERE element, but ER $\beta$ seems to be a weaker transactivator (Cowley \& Parker 1999).

To date, only a limited number of genes have been shown to be regulated by this classical mode of action. E2 also transcriptionally regulates target genes via ERs though a non-ERE mode of action. These effects are mediated through promoter elements that bind various transcription factors (e.g., AP-1-binding sites and Sp1binding sites; Webb et al. 1998, Porter et al. 1997). At these sites, ER $\alpha$ and $\operatorname{ER} \beta$ could have opposite transcriptional effects in some circumstances. In fact, $\mathrm{ER} \beta$ is not able to potentiate an AP-1-containing reporter in the presence of E2 in a tissue-specific manner (Paech et al. 1997). In addition, E2 interaction with ER $\beta$ does not result in the formation of a transcriptionally active complex at a promoter containing Sp1 elements (Saville et al. 2000). More significant differences are reported between ER $\beta$ and
$\mathrm{ER} \alpha$ actions with respect to their ability to activate rapid E2-induced signals. The activation of ERK/ MAPK, PI3K/AKT, and PKC, rapidly generated after $\mathrm{E} 2$ binding to ER $\alpha$ in different cell lines, are all defined as necessary and sufficient for E2-induced G1 to S phase progression, to increase survival pathways (e.g., Bcl-2), and to regulate the transcription of AP-1- and Sp1-dependent genes important for cell cycle modulation (e.g., cyclin D1). Interestingly, the transcriptional activity of the E2-ER $\alpha$ complex could be inhibited by pre-treating cells with the ERK inhibitors PD98059 and U0126 (Levin 2005, Marino et al. 2005).

Limited, conflicting data are reported for ER $\beta$ mediated rapid signals. A subpopulation of ER $\beta$ transfected in CHO cells is capable of activating $\mathrm{IP}_{3}$ production, ERK/MAPK and c-Jun kinase phosphorylation (Razandi et al. 1999). Geraldes and coworkers reported that E2 reduces ERK/MAPK activity through ER $\beta$ stimulation in porcine smooth muscle cells (Geraldes et al. 2003). Moreover, contradictory evidence on the ability of ER $\beta$ to activate or inactivate Src and p38 kinases have also been reported (Castoria et al. 2001, Kousteni et al. 2001, Geraldes et al. 2003, Mori-Abe et al. 2003). We recently reported the ER $\beta-E 2$ 


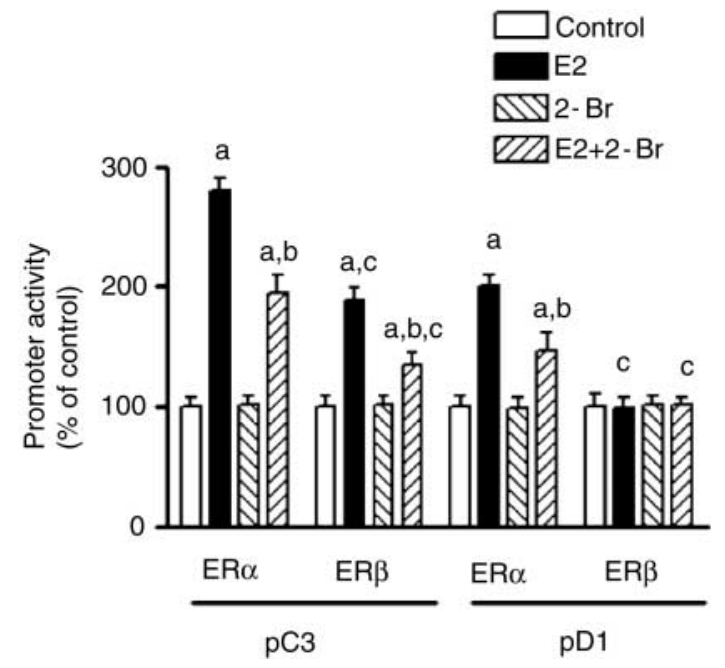

Figure 9 Role of ERs palmitoylation on the E2-induced genomic activity in HeLa cells. Cells were co-transfected with human $\mathrm{ER} \beta$ or human $\mathrm{ER} \alpha$ expression vectors together with pC3-luciferase (pC3) or pD1-luciferase (pD1) constructs and pre-treated 30 min with $10 \mu \mathrm{M}$ PAT inhibitor $2-\mathrm{Br}$ before E2 administration (10 $\mathrm{nM}$ for $6 \mathrm{~h}$ ). The data are the mean values \pm S.D. of five different experiments. $P<0.001$ was calculated with Bonferroni's test: a, significantly different from control value (open bar); b, significantly different from E2 stimulated samples; and c, significantly different from ER $\alpha$ transfected HeLa cells.

complex ability to activate p38/MAPK in the ER-devoid HeLa cells transiently transfected with the ER $\beta$ expression vector (Acconcia et al. 2005b). The discrepancies reported in these studies could be due to the different cellular models utilized, in which ER $\beta$ is over-expressed, or both $\operatorname{ER} \alpha$ and $\operatorname{ER} \beta$ are co-expressed, or different ER $\beta$ splicing forms could even be present. This further enhances the complexity in the spectrum of potential cellular responses to E2.

Here, using colon cancer cells which contain only one ER $\beta$ isoform, we demonstrated that $\operatorname{ER} \beta$ is localized to the plasma membrane and originate rapid signal transduction cascades important for anti-proliferative effects of E2. In fact, we prove that ER $\beta$ undergoes PAT-dependent palmitoylation even if this isoform is a poor substrate for PAT as compared to $\mathrm{ER} \alpha$ (Fig. 2). In addition, the localization to the membrane is dependent on ER $\beta$ palmitoylation since the PAT inhibitor impairs ER $\beta$ from localizing at the membrane and from interacting with caveolin-1. Similar to that reported for ER $\alpha$ is the time- and concentration-dependent negative regulation of ER $\beta$ palmitoylation exerted by E2 (Fig. 3).

Palmitoylation function must be considered more than a simple membrane association of otherwise soluble proteins. In fact, the palmitoylation status of several proteins has also been linked to their activation and their movement within membrane subdomains. As an example, de-palmitoylation of eNOS increases in response to treatment of cells with bradykinin (Robinson et al. 1995) and de-palmitoylation has a subtle effect on membrane distribution of G-proteins affecting their partitioning within membrane subdomains (Smotrys \& Linder 2004). Thus, palmitate addition is a dynamic modification that is continually turning over on cellular proteins. ER $\beta$ and ER $\alpha$ do not contain a trans-membrane domain (Zhang et al. 2004) or consensus sequences for miristoylation or prenylation (Acconcia et al. 2003), thus their ability to associate with scaffolding or/and signaling proteins at the plasma membrane seems principally due to palmitoylation (Acconcia et al. 2005b, Levin 2005). In the resting state, ER $\beta$ is localized mainly in the cytosol and nucleus of DLD-1 cells and only a little amount of receptor is tethered with caveolin-1 (Fig. 5). After E2 stimulation, ER $\beta$ undergoes de-palmitoylation, which increases receptor-caveolin-1 association (Fig. 5) and, thus, its presence at the plasma membrane (Fig. 6). E2 stimulation of ER $\alpha$-containing cells decreases receptor palmitoylation with a kinetics similar to that reported for ER $\beta$ (Fig. 3). The E2dependent de-palmitoylation decreases ER $\alpha$-caveolin1 association allowing ER $\alpha$ association with adaptors and/or signaling proteins (e.g., MNAR, Src, tyrosine kinase receptors), which in turn give rise to rapid signaling cascades (e.g., MAPK and PI3K; Levin 2005, Marino et al. 2005, Song et al. 2005, Leclercq et al. 2006). This does not occur in the presence of ER $\beta$. It has been reported that intact $\mathrm{A} / \mathrm{B}$ domain and tyrosine 537 in $\mathrm{E}$ domain of $\mathrm{ER} \alpha$ are both required for receptor interaction with Src in the MNAR-ER $\alpha-$ Src complex and the in vitro association between ER $\beta$ and MNAR has been reported (Barletta et al. 2004, Greger et al. 2006). Although ER $\beta$ possess a tyrosine residue at 488 , which could be subjected to phosphorylation, the ER $\alpha$ and ER $\beta$ A/B domain differ in both length and amino acid sequence, exhibiting a low amino acid identity (Ascenzi et al. 2006). Moreover, present data indicate that no association between ER $\beta$ and MNAR and Src was present in DLD-1 cells before and after E2 stimulation (Fig. 4). On the other hand, E2 increased ER $\beta$ level (Chiang et al. 2000, Matthews \& Gustafsson 2003 and present data) and its association with caveolin-1 (Fig. 5). As a whole, these data raise the intriguing possibility that the short $\mathrm{A} / \mathrm{B}$ domain of $\mathrm{ER} \beta$ could facilitate the E2-induced association between ER $\beta$ and caveolin-1, impairing its association with MNAR and Src. As a consequence, ERK and AKT 
activation does not occur. Experiments in our laboratory are in progress to better define this pathway.

ERK/MAPK as well as PI3K/AKT cascades cooperate in ER $\alpha-E 2$ induced cell proliferation and cell survival, enhancing the expression of the antiapoptotic protein (Bcl-2) and promoting the G1/S transition via the enhancement of cyclin D1 expression (Marino et al. 2002, 2003). In addition, the E2-ER $\alpha$ complex rapidly increased p38/MAPK phosphorylation but the contemporary increase of Bcl-2 levels, mediated by ERK/MAPK and PI3K/AKT pathways, impairs the prolonged p38 activation and the downstream effects of this kinase (Acconcia et al. 2005b). On the contrary, the rapid increase of p38 phosphorylation induced by the E2-ER $\beta$ complex is not modulated by ERK/MAPK and PI3K/AKT pathways, thus a more prolonged p38 phosphorylation occurs (Acconcia et al. 2005b; Fig. 6).

The ER $\beta$ palmitoylation is important for E2-induced cell functions. In fact, ER $\beta-p 38$ association and E2induced prolonged activation of this kinase is prevented by the PAT inhibitor 2-Br (Fig. 6). Moreover, ER $\beta$ palmitoylation is necessary for the p38dependent activation of downstream pro-apoptotic cascade, which involves the caspase- 3 activation and PARP cleavage (Fig. 7). To evaluate the impact of palmitoylation on E2-transcriptional effects, we compared ER $\beta$ and ER $\alpha$ in a cellular context, which contained the same co-activators. As expected, ER $\beta$ is a weaker transactivator than ER $\alpha$. The palmitoylation of ER $\beta$ scarcely influences ER $\beta$ genomic activities (i.e., ERE-containing gene promoter transcription). Similar results were obtained in ER $\alpha$-containing cells, indicating that the rapid palmitoylation-dependent signal transduction pathways are important for the complete transcriptional activity of ERs. This could be due to the ability of such cytosolic signals to modulate the co-activator recruitment and the chromatin activation status (Smith \& O'Malley 2004). ER $\beta$ and ER $\alpha$ have opposite effects in mediating the E2-induced transcription of cyclin D1 (i.e., non-ERE-containing gene promoter). As expected, ER $\beta$ was unable to induce cyclin D1 promoter transcription, whereas a critical requirement of $\mathrm{ER} \alpha$ palmitoylation for cyclin D1 promoter transcription was present.

In conclusion, present findings indicate that palmitoylation localizes ER $\beta$ at the plasma membrane, and this even if only in little quantity, directs several E2 effects, which allow the protective effect of this hormone in colon cancer. These data, showing the molecular mechanism, which rapidly follows E2 entry in ER $\beta$-containing cells, further sustain the tumor suppressor function played by this receptor isoform.
Although ER $\alpha$ is palmitoylated, the outcome effects in cell physiology are opposite to that reported for ER $\beta$. Thus, the expression of each ER isoform and/or their co-expression in the cells could account for the different E2-dependent modulation of cell proliferation reported.

\section{Acknowledgements}

The authors wish to thank Prof. Paolo Ascenzi (Department of Biology, University 'Roma Tre', V.le G Marconi, 446, I-00146 Rome, Italy) for helpful and critical discussions. The generous gift of DLD-1 cells from Dr Aldo Cavallini (Biochemistry Laboratory, I R C C S 'de Bellis', V della Resistenza, Castellana Grotte, I-70013 Bari, Italy) and of human ER $\beta$ expression vector from Prof. Masami Muramatsu (Research Center for Genomic Medicine, Saitama Medical School, 38 Morohongo, Moroyama, Iruma-gun, Saitama 350-0495, Japan) are gratefully acknowledged. The authors express gratitude to Dr Fulvio Florenzano (IRCCS, 'Fondazione S Lucia', V Ardeatina, Rome, Italy) for helpful advice in performing confocal microscopic analysis. The editorial assistance of Mr Peter De Muro is also acknowledged. This work was supported by grants from MIUR (COFINPRIN 2004) to M M. The authors declare that there is no conflict of interest that would prejudice the impartiality of this scientific work.

\section{References}

Acconcia F, Bocedi A, Ascenzi P \& Marino M 2003 Does palmitoylation target estrogen receptors to plasma membrane caveolae? IUBMB Life 55 33-35.

Acconcia F, Ascenzi P, Fabozzi G, Visca P \& Marino M 2004 $S$-Palmitoylation modulates human estrogen receptor- $\alpha$ functions. Biochemical and Biophysical Research Communications 316 878-883.

Acconcia F, Totta P, Ogawa S, Cardillo I, Inoue S, Leone S, Trentalance A, Muramatsu M \& Marino M 2005a Survival versus apoptotic $17 \beta$-estradiol effect: role of $\mathrm{ER} \alpha$ and ER $\beta$ activated non-genomic signalling. Journal of Cellular Physiology 203 193-201.

Acconcia F, Ascenzi P, Bocedi A, Spisni E, Tomasi V, Trentalance A, Visca P \& Marino M $2005 b$ Palmitoylation-dependent estrogen receptor $\alpha$ membrane localization: regulation by $17 \beta$-estradiol. Molecular Biology of the Cell 16 231-237.

Acevedo ML \& Kraus WL 2004 Transcriptional activation by nuclear receptors. In: Essays in Biochemistry: The Nuclear Receptor Superfamily, pp 73-88. Ed IJ McEwan. London: Portland Press.

Ascenzi P, Bocedi A \& Marino M 2006 Structure-function relationship of estrogen receptor $\alpha$ and $\beta$ : impact on human health. Molecular Aspects of Medicine 27 299-402. 
Bandera CA, Takahashi H, Behbakht K, Liu PC, Li Volsi VA, Benjamin I, Morgan MA, King SA, Rubin SC \& Boyd J 1997 Deletion mapping of two potential chromosome 14 tumor suppressor gene loci in ovarian carcinoma. Cancer Research 57 513-515.

Bardin A, Boulle N, Lazennec G, Vignon F \& Pujol P 2004 Loss of ER $\beta$ expression as a common step in estrogendependent tumor progression. Endocrine Related Cancer 11 537-551.

Barletta F, Wong CW, McNally C, Komm BS, Katzenellenbogen B \& Cheskis BJ 2004 Characterization of the interactions of estrogen receptor and MNAR in the activation of cSrc. Molecular endocrinology 18 1096-1108.

Campbell-Thompson M, Lynch J \& Bhardwaj B 2001 Expression of estrogen receptor (ER) subtypes ER beta isoforms in colon cancer. Cancer research 61 632-640.

Castoria G, Migliaccio A, Bilancio A, Di Domenico M, de Falco A, Lombardi M, Fiorentino R, Varricchio L, Barone MV \& Auricchio F 2001 PI3-kinase in concert with Src promotes the S-phase entry of oestradiol-stimulated MCF-7 cells. EMBO Journal 20 6050-6059.

Chambliss KL, Yuhanna IS, Anderson RG, Mendelsohn ME \& Shaul PW 2002 ER $\beta$ has nongenomic action in caveolae. Molecular endocrinology 16 938-946.

Cheng J, Lee EJ, Madison LD \& Lazennec G 2004 Expression of estrogen receptor $\beta$ in prostate carcinoma cells inhibits invasion and proliferation and triggers apoptosis. FEBS Letters 566 169-172.

Chiang C-H, Cheng KW, Igarashi S, Nathwani PS \& Leung PCK 2000 Hormonal regulation of estrogen receptor $\alpha$ and $\beta$ gene expression in human granulosa-luteal cells in vitro. The Journal of Clinical Endocrinology and Metabolism 85 3828-3839.

Couse JF \& Korach KS 1999 Estrogen receptor null mice: what have we learned and where will they lead us? Endocrine reviews 20 358-417.

Cowley SM \& Parker MG 1999 A comparison of transcriptional activation by $\mathrm{ER} \alpha$ and $\mathrm{ER} \beta$. The Journal of Steroid Biochemistry and Molecular Biology 69 165-175.

Fixemer T, Remberger K \& Bonkhoff H 2003 Differential expression of the estrogen receptor beta in human prostate tissue, premalignant changes, and in primary, metastatic, and recurrent prostatic adenocarcinoma. Prostate 54 79-87.

Foley EF, Jazaeri AA, Shupnik MA, Jazaeri O \& Rice LW 2000 Selective loss of estrogen receptor beta in malignant human colon. Cancer Research 60 245-248.

Geraldes P, Sirois MG \& Tanguay JF 2003 Specific contribution of estrogen receptors on mitogen-activated protein kinase pathways and vascular cell activation. Circulation Research 93 399-405.

Greger JG, Guo Y, Henderson R, Ross JF \& Cheskis BJ 2006 Characterization of MNAR expression. Steroid 71 317-322.

Herynk MH \& Fuqua SA 2004 Estrogen receptor mutations in human disease. Endocrine reviews 25 869-898.
Herbert B, Truss M, Beato M \& Müller R 1994 Inducibile regulatory elements in the human cyclin $\mathrm{D}_{1}$ promoter. Oncogene 9 1295-1304.

Horvath LG, Henshall SM, Lee CS, Head DR, Quinn DI, Makela S, Delprado W, Golovsky D, Brenner PC, O’Neill G, Kooner R, Stricker PD, Grygiel JJ, Gustafsson J-A \& Sutherland RL 2001 Frequent loss of estrogen receptor- $\beta$ expression in prostate cancer. Cancer Research 61 5331-5335.

Imamov O, Shim GJ, Warner M \& Gustafsson J-A 2005 Estrogen receptor beta in health and disease. Biology of Reproduction 73 866-871.

Iwao K, Miyoshi Y, Egawa C, Ikeda N \& Noguchi S 2000 Quantitative analysis of estrogen receptor- $\beta$ mRNA and its variants in human breast cancers. International Journal of Cancer 88 733-736.

Kasahara K, Taguchi T, Yamasaki I, Kamada M, Yuri K \& Shuin T 2002 Detection of genetic alterations in advanced prostate cancer by comparative genomic hybridisation. Cancer, Genetics and Cytogenetics 137 59-63.

Koehler KF, Helguero LA, Haldosen LA, Warner M \& Gustafsson J- $\AA 2005$ Reflections on the discovery and significance of estrogen receptor $\beta$. Endocrine Reviews 26 465-478.

Konstantinopoulos PA, Kominea A, Vandoros G, Sykiotis GP, Andricopoulos P, Varakis I, Sotiropoulou-Bonikou G \& Papavassiliou AG 2003 Oestrogen receptor beta (ER $\beta$ ) is abundantly expressed in normal colonic mucosa, but declines in colon adenocarcinoma paralleling the tumour's dedifferentiation. European Journal of Cancer 39 1251-1258.

Kousteni S, Bellido T, Plotkin LI, O’Brien CA, Bodenner DL, Han L, Han K, Di Gregorio GB, Katzenellenbogen JA, Katzenellenbogen BS, Roberson PK, Weinstein RS, Jilka RL \& Manolagas SC 2001 Nongenotropic, sex-nonspecific signaling through the estrogen or androgenreceptors: dissociation from transcriptional activity. Cell 104 719-730.

Leclercq G, Lacroix M, Laios I \& Laurent G 2006 Estrogen receptor $\alpha$ : impact of ligands on intracellular shuttling and turnover rate in breast cancer cells. Current Cancer Drug Targets 6 39-64.

Levin ER 2005 Integration of the extra-nuclear and nuclear actions of estrogen. Molecular Endocrinology 19 1951-1959.

Loveday RL, Greenman J, Simcox DL, Speirs V, Drew PJ, Monson JR \& Kerin MJ 2000 Genetic changes in breast cancer detected by comparative genomic hybridisation. International Journal of Cancer 15 494-500.

Marino M, Pallottini V \& Trentalance A 1998 Estrogens cause rapid activation of IP3-PKC- $\alpha$ signal transduction pathway in HEPG2 cells. Biochemical and Biophysical Research Communications 245 254-258.

Marino M, Acconcia F, Bresciani F, Weisz Z \& Trentalance A 2002 Distinct nongenomic signal transduction pathways controlled by $17 \beta$-estradiol regulate DNA synthesis and cyclin $\mathrm{D}_{1}$ gene transcription in HepG2 cells. Molecular Biology of the Cell 13 3720-3729. 
Marino M, Acconcia F \& Trentalance A 2003 Biphasic estradiol induced AKT phosphorylation is modulated by PTEN via MAP kinase in HepG2 cells. Molecular Biology of the Cell 14 2583-2591.

Marino M, Acconcia F \& Ascenzi P 2005 Estrogen receptor signalling: bases for drug actions. Current drug targets. Immune, Endocrine and Metabolic Disorders 5 305-314.

Marino M, Galluzzo P, Leone S, Acconcia F \& Ascenzi P 2006 Nitric oxide impairs the $17 \beta$-estradiol-induced apoptosis in human colon adenocarcinoma cells. Endocrine Related Cancer 13 559-569.

Matthews J \& Gustafsson J- 2003 Estrogen signalling: a subtle balance between ER $\alpha$ and ER $\beta$. Molecular Interventions 3 281-292.

Mori-Abe A, Tsutsumi S, Takahashi K, Toya M, Yoshida M, Du B, Kawagoe J, Nakahara K, Takahashi T, Ohmichi M \& Kurachi H 2003 Estrogen and raloxifene induce apoptosis by activating p38 mitogen-activated protein kinase cascade in synthetic vascular smooth muscle cells. Journal of Endocrinology 178 417-426.

Paech K, Webb P, Kuiper GG, Nilsson S, Gustafsson J-Å, Kushner PJ \& Scanlan TS 1997 Differential ligand activation of estrogen receptors ER $\alpha$ and ER $\beta$ at AP-1 sites. Science 277 1508-1510.

Paruthiyil S, Parmar H, Kerekatte V, Cunha GR, Firestone GL \& Leitman DC 2004 Estrogen receptor $\beta$ inhibits human breast cancer cell proliferation and tumor formation by causing a G2 cell cycle arrest. Cancer Research 64 423-428.

Pettersson K, Grandien K, Kuiper GG \& Gustafsson J-Å 1997 Mouse estrogen receptor $\beta$ forms estrogen response element-binding heterodimers with estrogen receptor $\alpha$. Molecular Endocrinology 11 1486-1496.

Porter W, Saville B, Hoivik D \& Safe S 1997 Functional synergy between the transcription factor Sp1 and the estrogen receptor. Molecular Endocrinology 11 1569-1580.

Razandi M, Pedram A, Greene GL \& Levin ER 1999 Cell membrane and nuclear estrogen receptors (ERs) originate from a single transcript: studies of ER $\alpha$ and ER $\beta$ expressed in Chinese hamster ovary cells. Molecular Endocrinology 13 307-319.

Resh MD 1999 Fatty acylation of proteins: new insights into membrane targeting of myristoylated and palmitoylated proteins. Biochimica et Biophysica ACTA 1451 1-16.

Robinson LJ, Busconi L \& Michel T 1995 Agonistmodulated palmitoylation of endothelial nitric oxide synthase. Journal of Biological Chemistry 270 995-998.
Roger P, Sahla ME, Makela S, Gustafsson J- $\AA$, Baldet P \& Rochefort H 2001 Decreased expression of estrogen receptor $\beta$ protein in proliferative preinvasive mammary tumors. Cancer Research 61 2537-2541.

Saville B, Wormke M, Wang F, Nguyen T, Enmark E, Kuiper G, Gustafsson J-Å \& Safe S 2000 Ligand-, cell-, and estrogen receptor subtype $(\alpha / \beta)$-dependent activation at GC-rich (Sp1) promoter elements. Journal of Biological Chemistry 275 5379-5387.

Smith CL \& O'Malley BW 2004 Coregulator function: a key to understanding tissue specificity of selective receptor modulators. Endocrine Reviews 25 45-71.

Smotrys JE \& Linder ME 2004 Palmitoylation of intracellular signaling proteins: regulation and function. Annual Review of Biochemistry 73 559-587.

Song RXD \& Santen RJ 2003 Apoptotic action of estrogen. Apoptosis 8 55-60.

Song RXD, Zhang Z \& Santen RJ 2005 Estrogen rapid action via protein complex formation involving $\mathrm{ER} \alpha$ and Src. Trends in Endocrinology and Metabolism 16 347-353.

Strom A, Hartman J, Foster JS, Kietz S, Wimalasena J \& Gustafsson J-A 2004 Estrogen receptor $\beta$ inhibits 17$\beta$-estradiol-stimulated proliferation of the breast cancer cell line T47D. PNAS 101 1566-1571.

Varner AS, Ducker CE, Xia Z, Zhuang Y, De Vos ML \& Smith CD 2003 Characterization of human palmitoylacyl transferase activity using peptides that mimic distinct palmitoylation motifs. Biochemical Journal 373 91-99.

Wada-Hiraike O, Imamov O, Hiraike H, Hultenby K, Schwend T, Omoto Y, Warner M \& Gustafsson J-A 2006 Role of estrogen receptor $\mathrm{b}$ in colonic epithelium. PNAS 103 2959-2964.

Webb P, Nguyen P, Shinsako J, Anderson C, Feng W, Nguyen MP, Chen D, Huang SM, Subramanian S, McKinerney E, Katzenellenbogen B, Stallcup MR \& Kushner PJ 1998 Estrogen receptor activation function 1 works by binding p160 coactivator proteins. Molecular Endocrinology 12 1605-1618.

Young J, Legget B, Gustafson C, Ward M, Searle J, Thomas L, Buttenshaw R \& Chenevix-Trench G 1993 Genomic instability occurs in colorectal carcinomas but not in adenomas. Human Mutation 2 351-354.

Zhang Z, Kumar R, Santen RJ \& Song RXD 2004 The role of adapter protein Shc in estrogen non-genomic action. Steroid 69 523-529. 